\title{
MANAGING BUILDING CHECKIST PLANS USING BUSCLIS
}

\author{
M. Zulfahmi Toh, A.Noraziah, M.Affendy Omardin, Nursharina Zainuddin \\ Faculty of Computer Systems \& Software Engineering, Universiti Malaysia Pahang, \\ 26300 Gambang, Pahang, Malaysia \\ Email: \{zulfahmi,noraziah\}@ ump.edu.my \\ Phone: +60169455363; Fax: +6095492144
}

\begin{abstract}
This paper presents the software namely Building Submission Checklist System (BUSCLIS). It has been developed to manage the submission of building checklist plans process in the construction industry. BUSCLIS helps to simplify the management for acquiescence data of building plan approval for the Local Authority (LA) and Country Planning in Malaysia through the web based system. BUSCLIS facilitates user through the computerization forms, which provides fast, efficient and effective service to the engineer, architect and contractor. Relevant and timely information manage by sophisticated BUSCLIS with the database management system MySQL.
\end{abstract}

Keywords: BUSCLIS, RAD, building plan, ICT, construction industry.

\section{INTRODUCTION}

Currently, construction companies needs Information and Communications Technology (ICT) to boost their capability in dealing with their business. However, to set up an information database for the construction industry would require a vast amount of resources especially in the ICT industries. In spite of the potential of Enterprise Resource Planning systems to increase productivity and internal ICT efficiency, construction companies hesitate to adopt these ICT solutions (Daniel 1998). Most of the activities in construction industry still use the conventional system. With the sight that construction is a business such others and clients now expect quality product, this view should begin to transform. Advance in ICT are causing dramatic changes in construction and build environment. Through ICT, thus it may help construction industry includes facilitate integration of various processes in the construction, standardization of information and faster the flow of information in industry.

In Malaysia, ICT applications turn into wisely due to the rapid developments of computer technologies and have variation the way of working environment. To support in the process, the utilization of ICT and automated software can provide efficiency and effective solutions to the problems of mass data and information handling (Daniel \& Moody, 1998; Thosmas \& Connoly, 2014). Database management system helps organization to manage or structure their data in a logical way (Noraziah, Nawsher, Ahmed, \& Abul, 2010). A computer can maintain accurate and consistent database, hence resulting is a better performance (Niemiec, 2007). One of the changes that have to make in construction industry is building plan approval checklist. Before the advent of system, organization kept all their data in manual or traditional files. Basically, the manual system workflow has many problems and very ineffective. The submission process of building plan endorsement in manual has required the usage of many forms and consumes time. Thus, it is error prone in approval the form. 
The significant requirement for the system arises as the result of set problem faced by user in the conventional system way of performing the relevant task. Current practice of a construction project involves submission of building checklist plans to the municipal authority for endorsement, is a very tedious and time-consuming procedure. The time occupied can range from weeks to months until the approval time. The submission of checklist process of the building plans to the relevant authorities needs many forms before submission. This include the standard checklist for building plan approval based on building categories, the fees for temporary building and other related forms. This will waste time and sometimes user makes mistakes by fulfill the wrong document. Every time, user needs to bring bundle of checklist paper and related document to be checked. This will damage the papers if it is in bad condition (rainy day) or may lost some of the checklist. By using conventional system, user cannot view the updated report for the approval submission. They have to wait until the endorsement time.

In this paper, we present the software and database design for Building Submission Checklist System (BUSCLI) using Entity Relationship Diagram (ERD). Furthermore BUSCLI simplify users by computerized all the forms accordance to the building categories, submission, endorsement or approval through online. Heuristic and software engineering method are deployed while developing this system.

\section{EXISTING SYSTEMS IN CONSTRUCTION INDUSTRY}

In this section, we review the conventional system and the existing systems include Esubmission, E-government and CWorks that relates to the construction industry.

\section{Conventional Systems}

The current practice of a construction project in Malaysia involves proposal of building checklist plans to the local or public authority for approval. Building plan approval process spans is a whole range of legislative and procedural rules and requirements input for a host of professionals, designer and specialist. Some variations exist in the submission and approval procedures between the different states although in the final analysis the basic requirement and steps quite similar (Harbans, 2006). In Malaysia the development approval process involves principally the following main stages which are:

- Land use conversion and subdivision approval

- Planning permission or Development Order approval

- Building plan approval

- Construction monitoring and enforcement

- Certificate of fitness for occupancy approval

- Maintenance and management

The authorities involved in the approval process, these are dictated by the locality of the project, whether it is State or city based, as the difference in the relevant authorities. A mutual list of such authorities would include Agriculture Department, Department of Environment, Department of Civil Aviation, District Land Office, Fire Service Department, Local Planning Authority and others related authorities. 


\section{Existing Systems}

In Malaysia, the information technology is growing up rapidly because of the implementation and development of Multimedia Super Corridor (MSC). E-submission system (Harbans, 2006) is a web application that enables all the submissions through online system. One of the application E-submission systems is E-Bangunan that has been implemented in the Majlis Perbandaran Sepang (MPS). It has been used by the people that involved submitting building plan to MPS. Numerous modules have been developed to make the system fulfill the user requirement and make the process submission and approval becomes more efficient. It allowed user to make application on new project and review the current status of their application in MPS through online. The application that provided by MPS are E-Bangunan, E-Rancang, E-Kejuruteraan, and E-Landskap. Figure 1 shows the main page of E-bangunan.

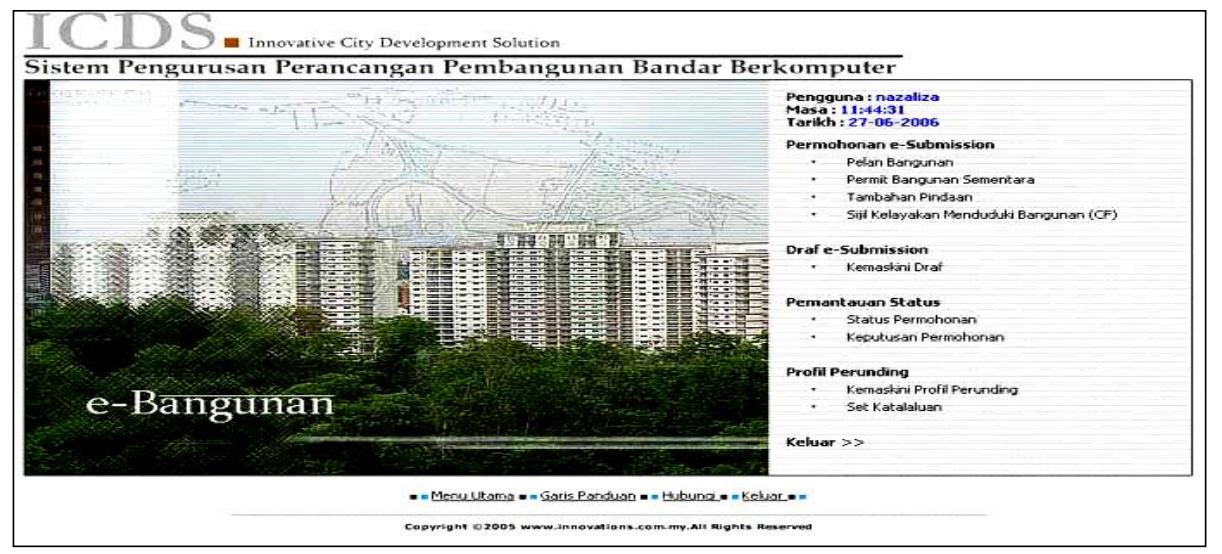

Figure 1. Main page of E-bangunan

E-bangunan is an application that is accessed via web browser over a network such as the Internet or an intranet. It helps their client by saving the cost, time and makes the approval of submission faster and easy. E- bangunan will ensure the data integrity where authorized user only can access into the system. In order to use this system, user need to register with MPS to acquire account and access the system. This system consists of four main modules which are:

a) Application for building plan;

b) Application permit for temporary building;

c) Application for additional/modification plan

d) Application qualification certificate for building

e) In each of sub-modules consist of five parts which are:

a) Application information

b) Location information

c) Owner information

d) Contractor information

e) Consultant information 


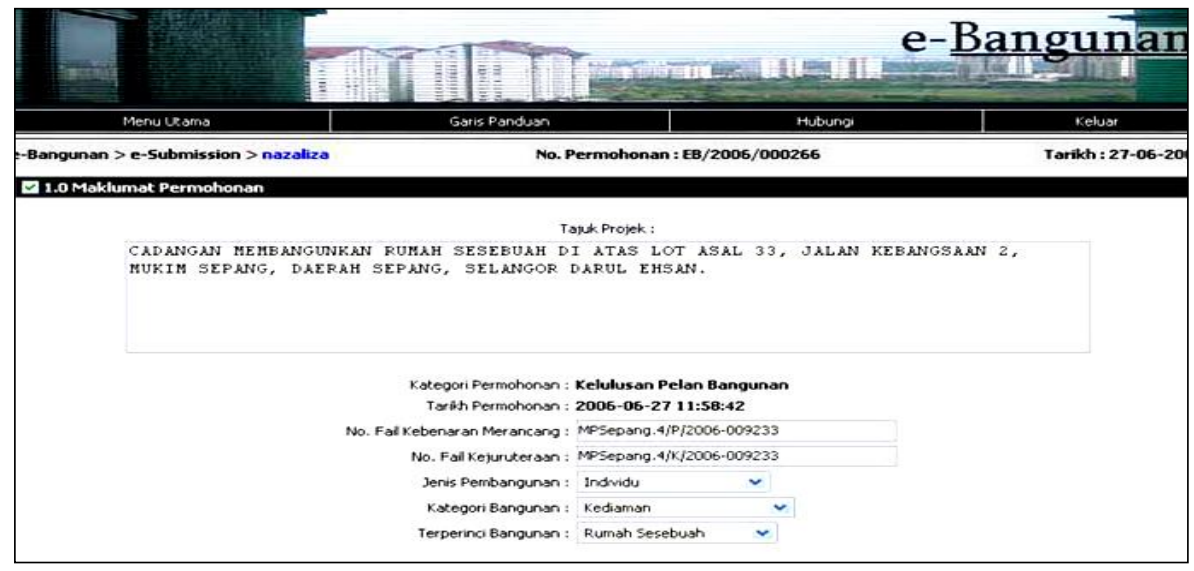

Figure 2. Application information form

Figure 2 shows the application information. User needs to fulfill the information needed such as application title, application category, date of application and other information needed.

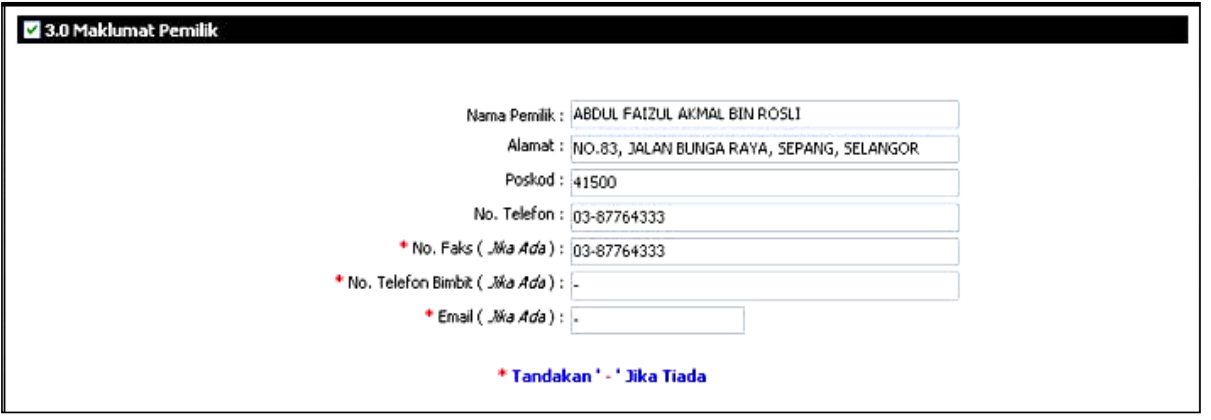

Figure 3. Owner information form

Figure 3 depicts the owner information form. User is required to fullfill all the information needed in the system such as name, address, postcode, phone number and others.

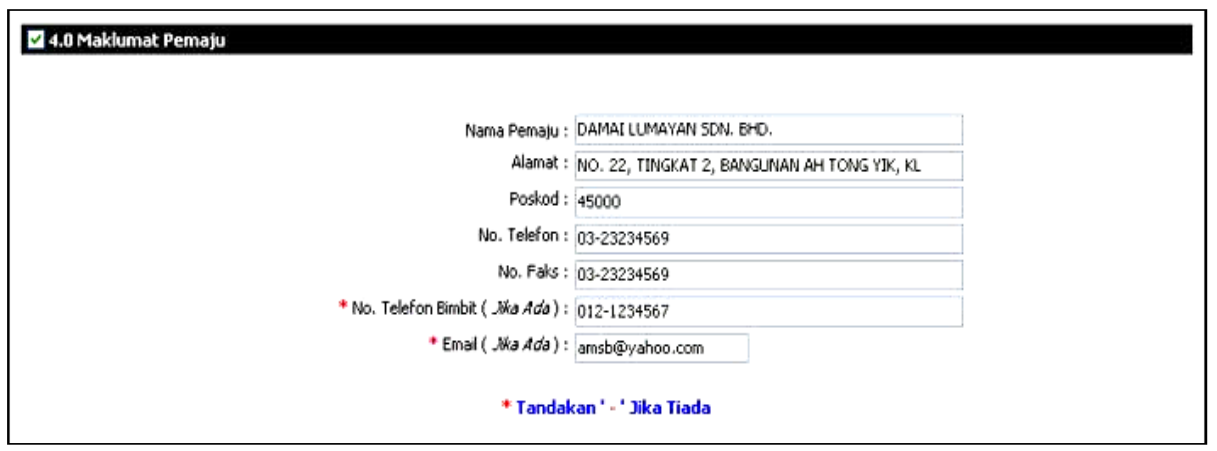

Figure 4. Contractor information form

Figure 4 shows the contractor information form. This form is used by contractor that deals with MPS. They need to fill the information such as name, address, postcode, phone number and other information. 


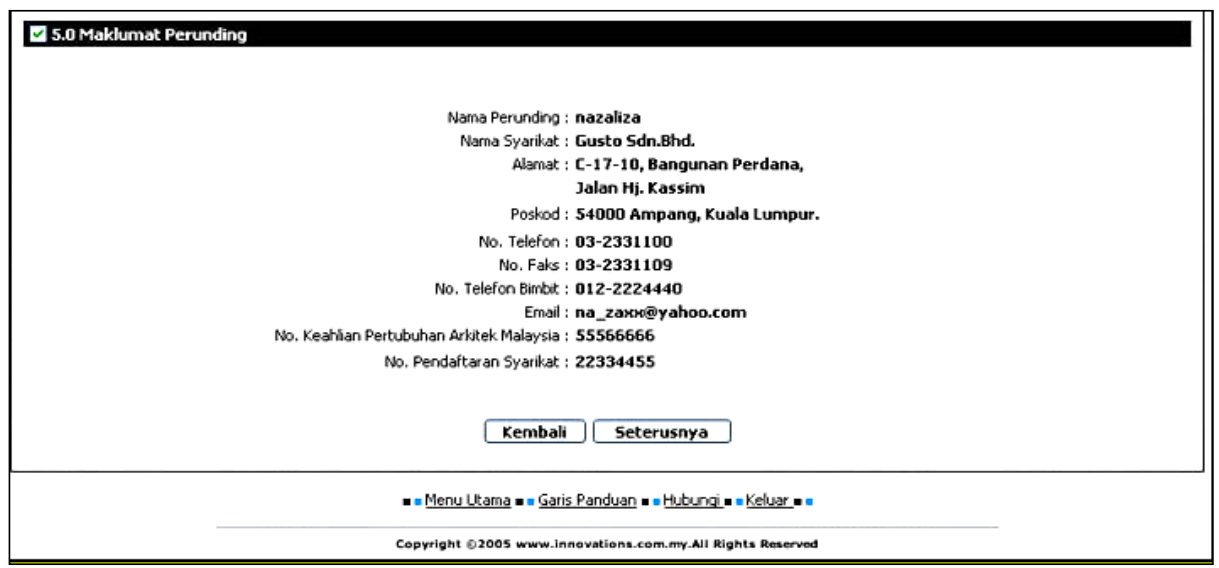

Figure 5. Consultant Information

Figure 5 shows the consultant information form. This form is used by consultant, which the information such as name, address, postcode, phone number, membership number and company registration no. Figure 6 and Figure 7 show others application in MPS that implemented the electronic form through the module E-Rancang, E-Kejuruteraan and ELandskap.

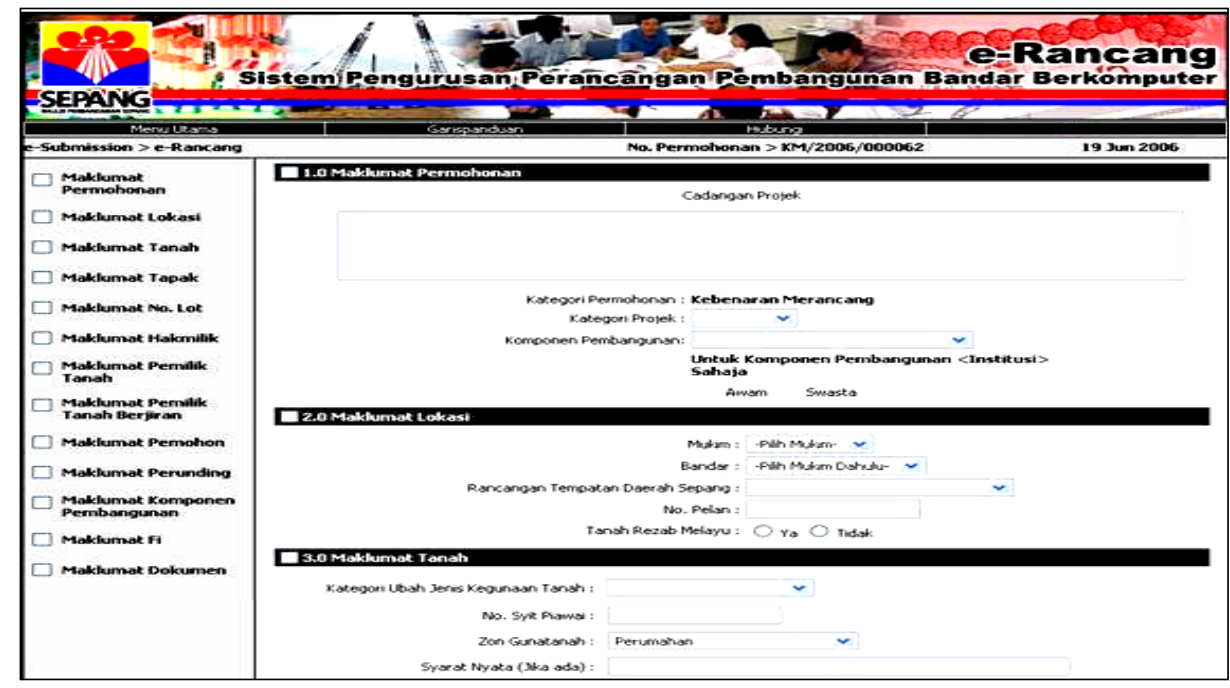

Figure 6. E-Rancang 


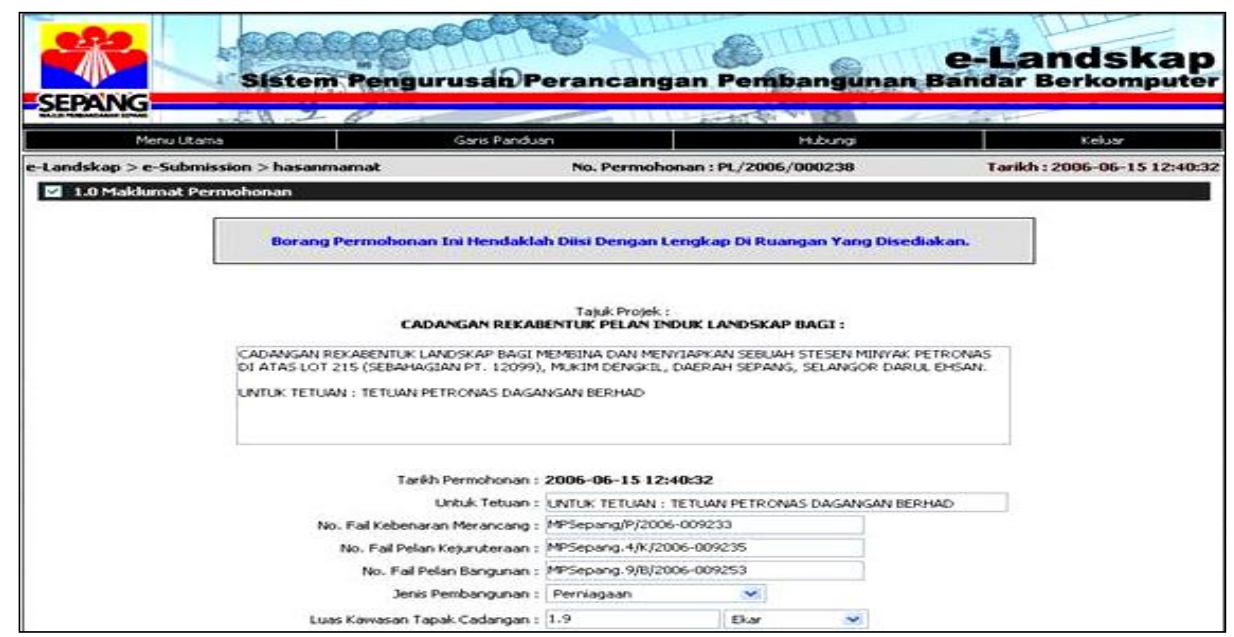

Figure 7. E-Landskap

E-government (Jelani, 2003) is a web application. This subsystem has improved both how the government operates within as well as how service is deliver to the Malaysian citizens. It seeks to improve the convenience, accessibility and quality of interactions with citizens and businesses; simultaneously, it will improve information flows and processes within government to improve the speed and quality of policy development, coordination and enforcement. Figure 8 shows main page of my EG, once of the famous government portal.

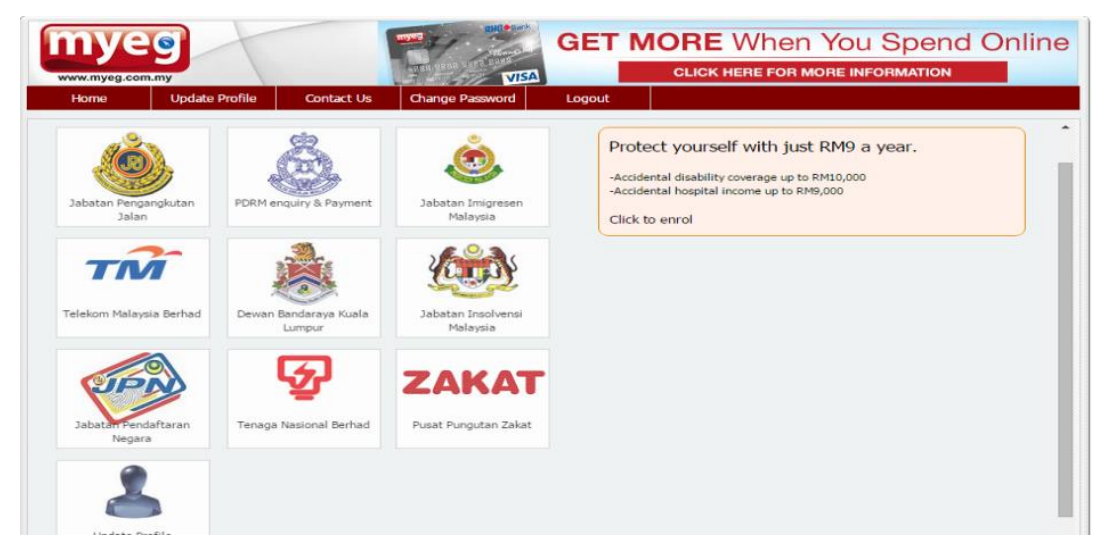

Figure 8. Main page of MyEG

CWorks Free (Cworks, 2011) is a Computerized Maintenance Management System (CMMS). Figure 9 shows the main page of CWorks. It is a Maintenance Software for Plant and Facility Management. The system is a standalone application. Its purpose is to ease people start on maintenance software to track and record their maintenance activities. This system is simple preventive maintenance freeware and free unrestricted software. It delivers various aids to organizations by delivering information to maintenance engineers and managers. 


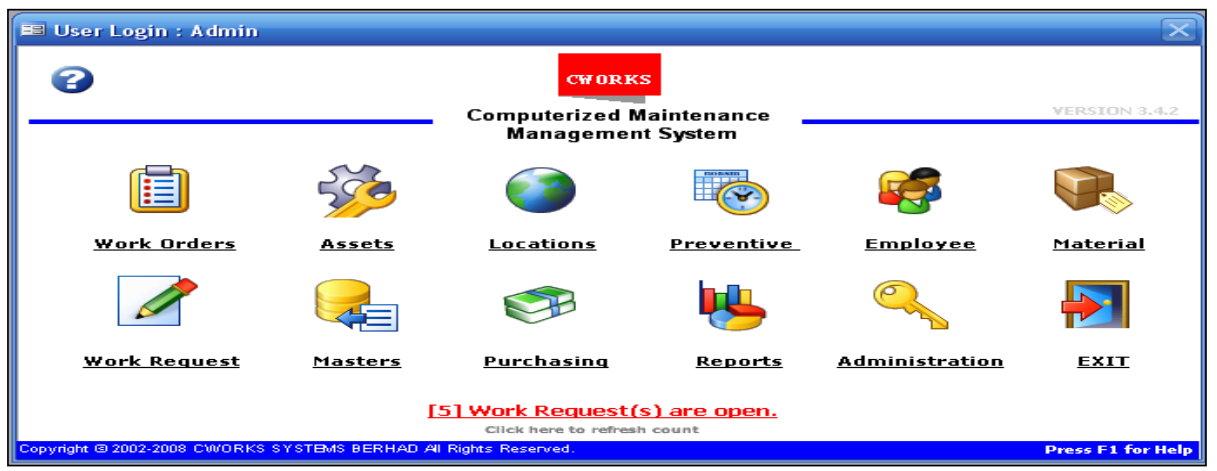

Figure 9. Main page of CWorks

The submission process of the building plans to the relevant authorities will require the authorities involved to check in details on the building design for building by-laws noncompliance (Mohd, Ng, Cher \& Zulizman, 2002). The Submission System of Urban Construction Archives (SSOUCA) (Jiangfeng, Weixiong, Kai \& Jingguang, 2010) is a software that now used by the Urban Construction Archives Agency of Shaoguan City and Zhenjiang City, China. It has been developed using with Windows Presentation Foundation (WPF) technology. WPF supports both online and offline work and is very suitable to be based on developing remote submission system. The platform of web server system used in SSOUCA is ASP.Net 3.5 and IIS 6.0, and one open source of WebGIS server is MapGuide used to render the spatial information within submitted archived. OpenLayers 2.8 is one of the open source Geographical Information System (GIS) viewer in JavaScript, is used to present archive map in the browser.

In opportunities of IT in construction industry of Iran are investigated in three categories (Ali \& Ali, 2009). It is pre-construction phase, construction phase and earthquake disaster mitigation. Many studies show that ICT can be used in these items to reduce the losses and increasing the benefits. Through management of documents that provides information about all aspects of project and to determine how processes can be managed to greatest effect using instantaneous engineering frameworks. It is necessary to understand the performance and behavior of the structures during the earthquake and significances arising after structures damage and IT can be used as a tool for educating people and reducing the losses of because of earthquake.

\section{METHODOLOGY}

During the development, Rapid Application Development (RAD) methodology is applied due it compresses the step-by-step development of conventional methods into an iterative process. RAD is appropriate for this system development because this software required to be completed in short times. The RAD involved developing and refining the data models, process models, and prototype in equivalent using an iterative process.

\section{Requirement Planning (Phase I)}

Requirement Planning is a stage consists of a review of the areas immediately associated with the proposal system. The review produces a comprehensive definition of the system requirements in terms of the functional requirement what system can do. In this stage user requirement is collected by doing interview with Mr. Amir, officer in 
Operational Submission Centre (OSC) at Majlis Perbandaran Kuantan. During the interview session, current system or manual system function is analyze, how the process and activities in current system, user in manual system and related document that required for analysis phase. In this phase all the requirement come from the OSC whereby the essentials of the system for example what the system can do, the features, and users of the system is well defined.

\section{Interview session}

To find out the information about current system interview session with Mr Amir who is Officer of Operational Submission Centre (OSC) in MPK. Opened interview session was held with him to know the flow of current system works and problems in using the current system.

\section{User design (Phase II)}

User design stage also known as Functional Design Stage, this stage uses workshops to model the system's data and processes and to build a working prototype of critical system components. In this stage, the data model will be model using Entity Relationship Diagram (ERD). ERD is a data modeling technique that creates a graphical representation of the entities, and the relationships between entities, within an information system (Roy, 2007). Overall process flow of this system is shown in Figure 10 . 


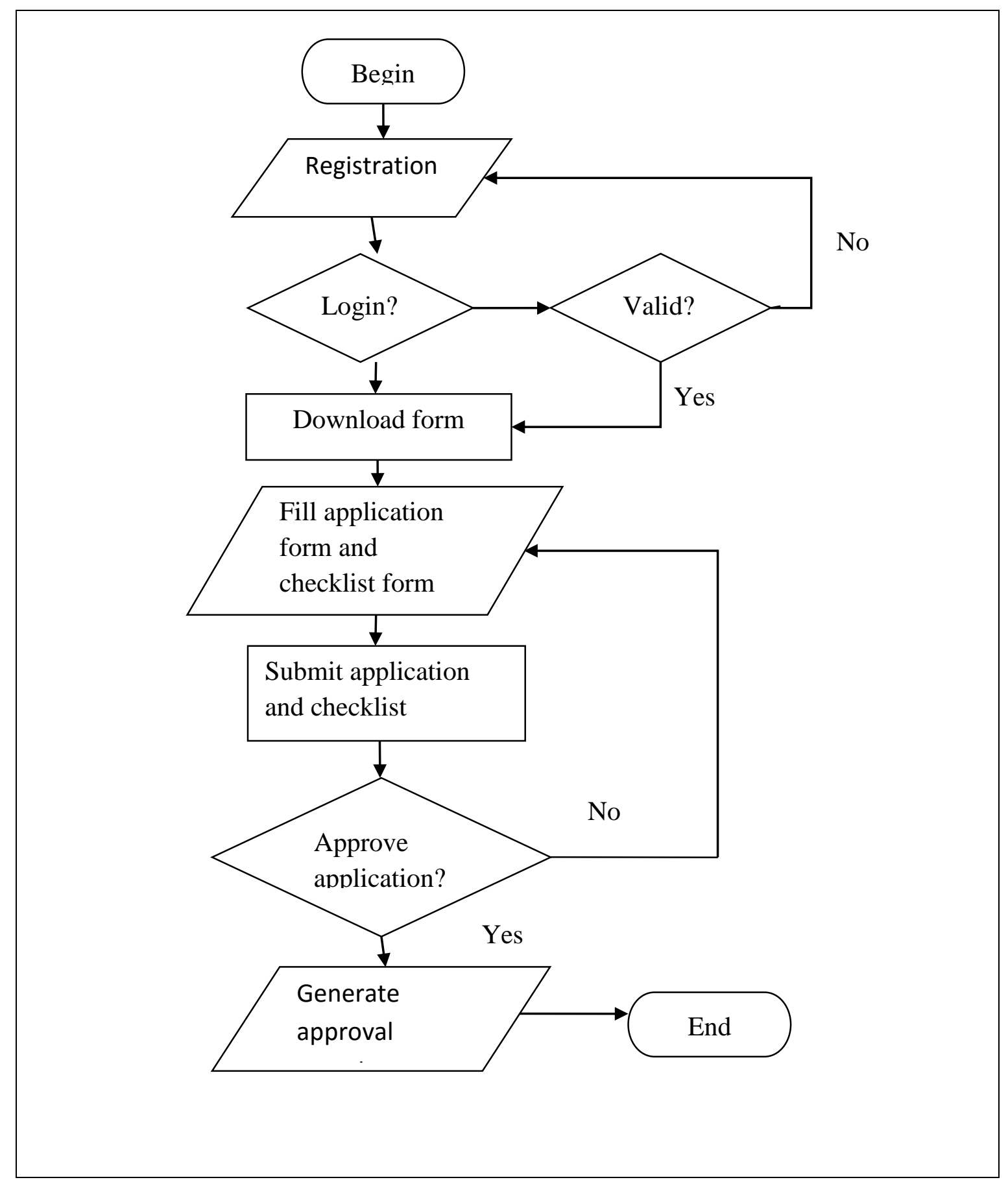

Figure 10. Flowchart of Building Submission Checklist System

\section{Construction Phase (Phase III)}

MySQL function as data store for the system to store all the information such as user profile, application and checklist profile. Other supported software use to make the construction phase works well. Before the development begins all the data dictionaries are execute in the MySQL database. 


\section{Cut over (Phase IV)}

Cutover phase also known as changeover phase. The cutover phases resembles the final task in software development lifecycle implementation phase, including data conversation, testing, change over to the new system and also user training. The detail of the process will be discussed in result and discussion sub topic.

\section{IMPLEMENTATION}

During the implementation, the software that been used to develop BUSCLIS are:

Table 1: Software specification

\begin{tabular}{|c|l|}
\hline Software & Purpose \\
\hline Windows XP Professional edition Version & $\begin{array}{l}\text { As the operating system for the } \\
\text { whole development phase }\end{array}$ \\
\hline Microsoft Word 2010 & Documentation \\
\hline Microsoft PowerPoint 2010 & Presentation \\
\hline MySQL Server 2005 & Database software \\
\hline Rational Rose & Analysis and design tool \\
\hline Peripheral Hypertext Preprocessor (PHP) & $\begin{array}{l}\text { For server-side scripting and user } \\
\text { interface in graphical applications. }\end{array}$ \\
\hline Acrobat Professional & $\begin{array}{l}\text { Used to design the graphical user } \\
\text { interface (GUI) and create forms. }\end{array}$ \\
\hline Xampp 1.6.3 version & $\begin{array}{l}\text { Apache to support MySQL } \\
\text { database. }\end{array}$ \\
\hline Kaspersky Anti-Virus 8.0 & Protection from virus \\
\hline
\end{tabular}

BUSCLIS is a web based application develops with PHP language and embedded with JavaScript as language development. To detect the error early, each module has been tested. Login module, Registration module, Approval module and Electronic form are the important module. 


\section{RESULT AND DISCUSSION}

\section{Registration Module}

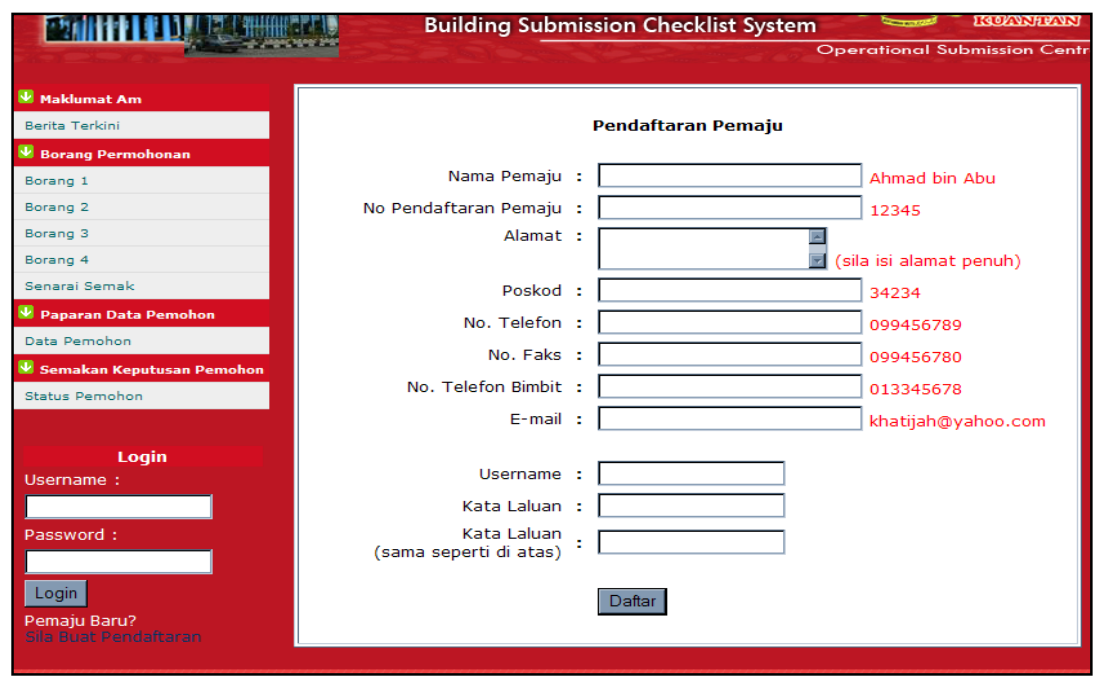

Figure 11. Registration Module

Figure 11 shows the registration module is used by new contractor which is did not have account. After the contractor fills all the required information, they have to fulfill the data related to the application such as project information, location, owner, and consultant that involved in the project. Figure 12 shows the location information that is required to be filled by the contractor.

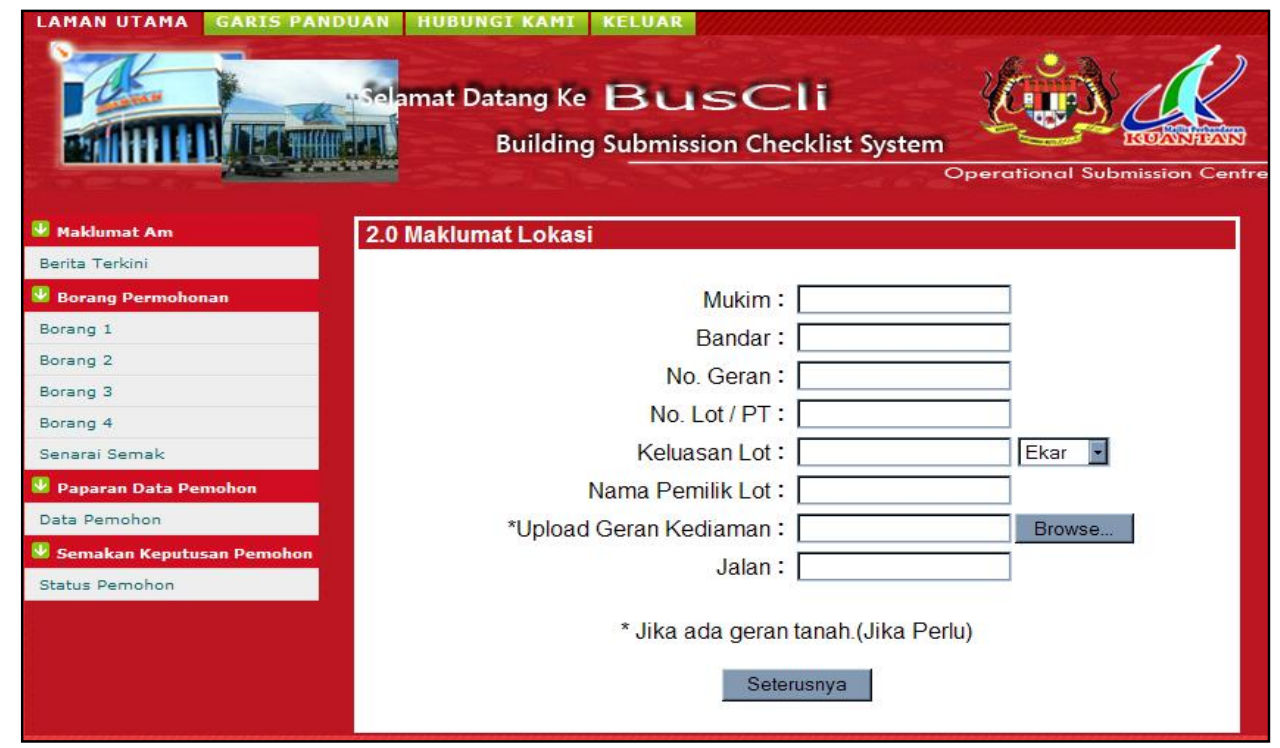

Figure 12. Location Information

After completed the registration, the contractor can login and access all the form such as $\mathrm{B}$ : (PB) 1 form for 'borang mengemukakan pelan bangunan', $\mathrm{B}$ : (PB) 2 form for 
'borang kiraan bayaran pelan', B: (PB) 3 form for 'borang perakuan pelan-pelan bangunan/struktur', and B: (PB) 3 form for 'borang pengesahan penggunaan $60 \%$ bahan tempatan semasa memohon kelulusan pelan'.

\section{Electronic Form}

Electronic form was provided in this system to help user in efficiency of submission the form. All the manual form has been online.

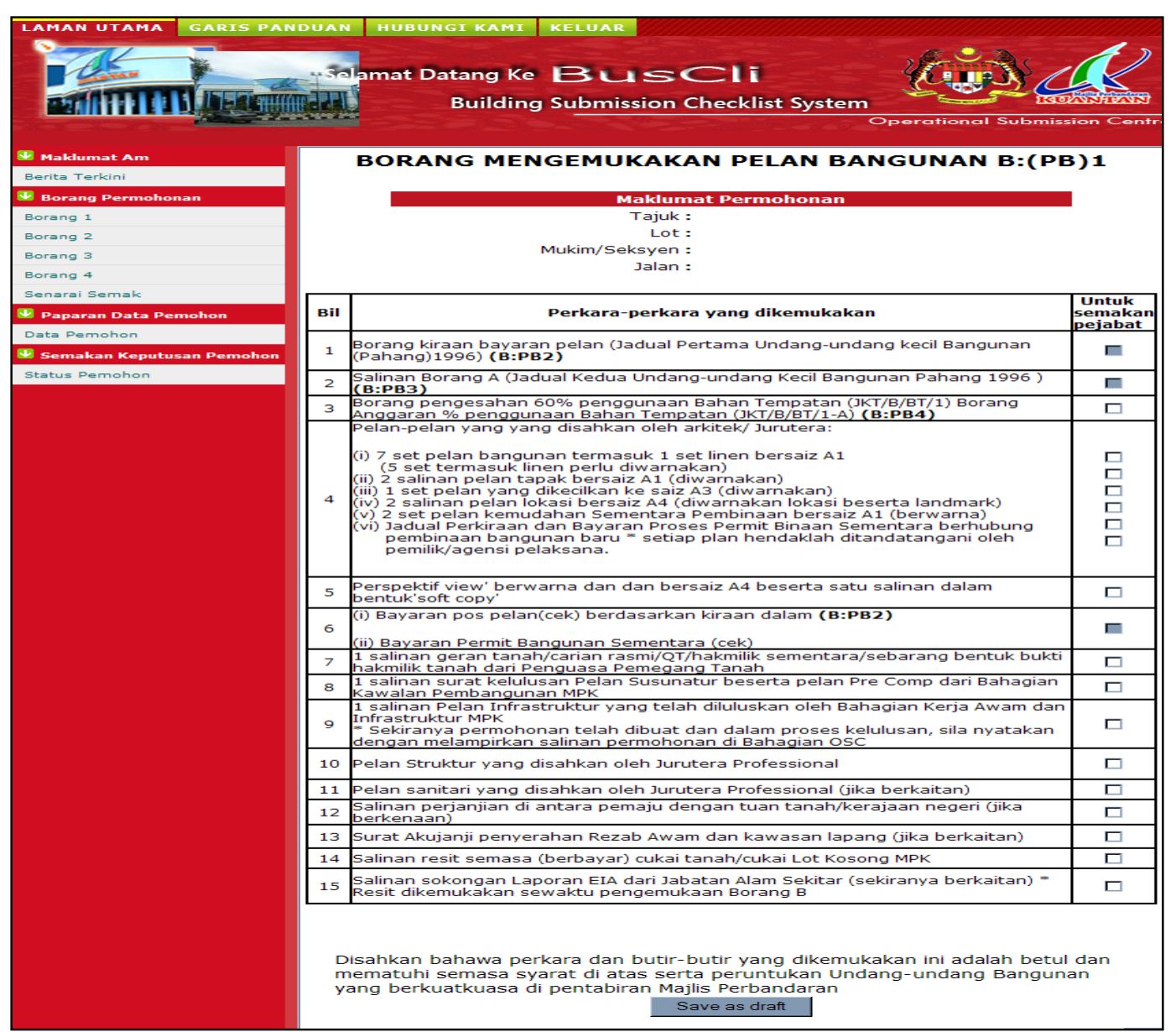

Figure 13. (PB) 1 form 


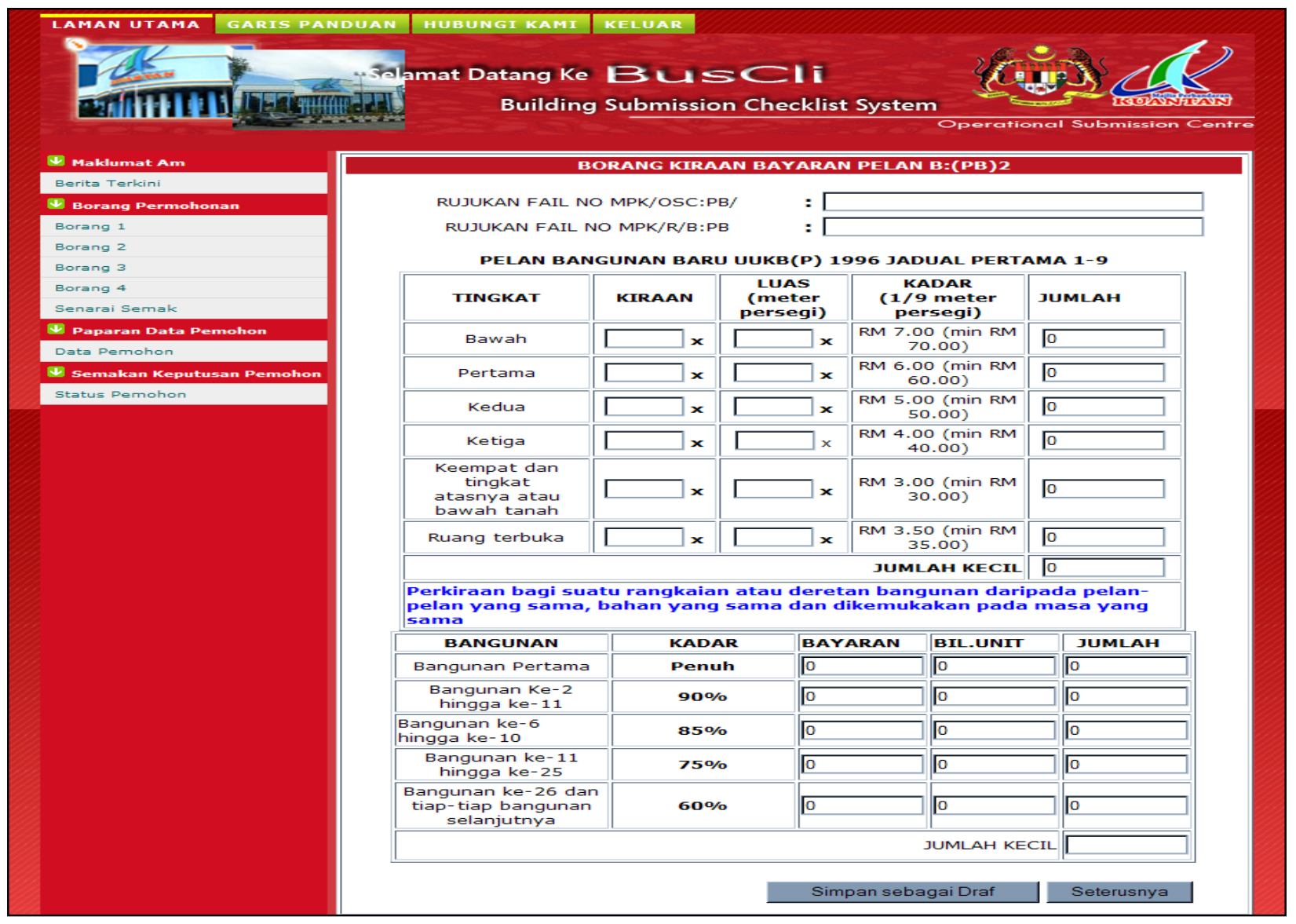

Figure 14. (PB) 2 form

Figure 14 shows the Electronic form that converts form manual form. All the data in the form used in the application of building plan. All the form can save as a draft if the contractor did not finished in full fill all the form which are B: (PB) 1 form, B: (PB) 2 form, (PB) 3 form and (PB) 4 form. Then, after finished all the form, the checklist which is will auto check to the data items related. After confirm with all the data, user need to click "hantar" and all the data will save in the database.

\section{Approval Module (Admin)}

In admin session, admin enable to view the entire project, the contractor data information and consultant data information. Admin will view detail on the project information and all information related to the project. Figure 15 shows the admin page of the system. 


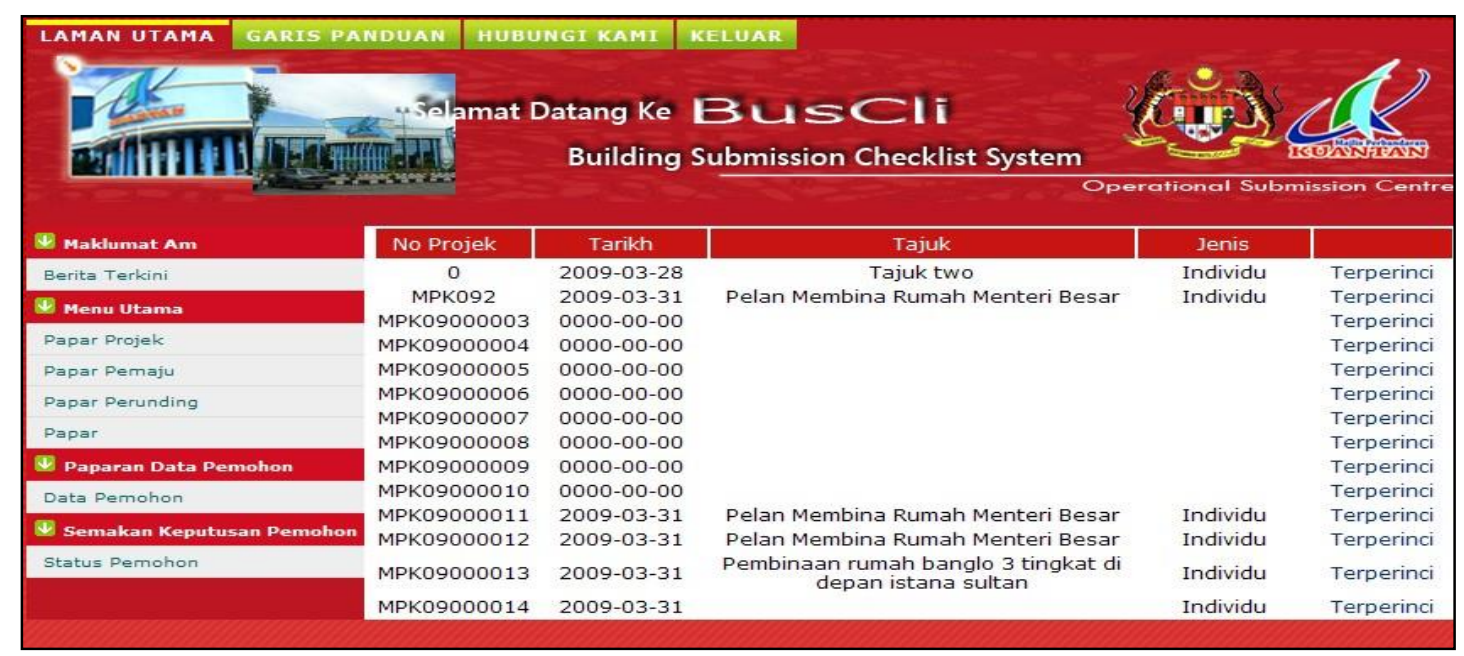

Figure 15. Admin main page

\section{CONCLUSIONS}

In this paper, we present the new design the development and process flow of the Building Submission Checklist System (BUSCLIS). We review the conventional system and existing computerize system, present the process flow, methodology and implementation of BUSCLIS. By using BUSCLIS, the management of database system is more efficient and liable, thus able to solve the problem occurs in manual or current operation in submission of building plan application. Thus, it can reduce time and make the approval process become faster, accurate with effective data control and besides support files sharing in network.

Further research and development can be done to enhance the system by developing a more user friendly graphical user interfaces. Besides, some new modules can be added into the system, as such submission all the items or form in JPEG file, or PDF file generator. For future development, other processes and activities in the submission of building plan can be computerized, not only for the checklist and computerized certain forms. Hence, this system can make data sharing between Local Authority (LA) in Malaysia. 


\section{REFERENCES}

Ali, H, Ali, K. (2009) Sustainable Development in Construction. World Academy of Science, Engineering and Technology. 2009.

CWorks (2011) - The Easy Route to Maintenance Reports, available at http://www.cworks.com.my/ on 24th Jan 2011.

Daniel, L. Moody. (1998). Metrics for Evaluating the Quality of Entity Relationship Models. Lecture Notes Computer Science., 1507: 211-225. Doi: 10.1007/b68220.

Harbans, S, K. (2006). Engineering and Construction Contracts Management. Auerbach Publication. Malaysian Construction Industry Master Plan, available at http://www.cidb.gov.my on June 2013.

Jelani, A, M. (2003). The Implementation of E-Government at the Local A Theorities Level with Emphasis on Planning and Development Approval Process. Key note Address at Leadership Seminar on Urban Management.

Jiangfeng, S., Hongdan, J., Weixiong, X., Kai, X., Jingguang, C. (2010) Urban Construction Archive Submission System with WPF Technology.

Mohd, J. S., Ng, K. W., Cher, D. T., Zulizman, B. (2002) Intelligent CAD Checker For Building Plan Approval. International Council for Research and Innovation in Building and Construction CIB, Aarhus School of Architecture, 12 - 14 June 2002.

Niemiec, R., (2007) Oracle Database 10 g Performances Tuning Tips and Techniques. ISBN: 13: 978-0-07-226305-9.

Noraziah, A, Nawsher, K, Ahmed, N. A, Abul, H. (2010). Novel Database Design for Student Information System, Journal of Computer Science, Science Publications, Vol. 6, No. 1, pp. 43-46.

Roy, P.V. (2007). Self Management and the Future of Software Design. Electronic Notes in Theoretical Computer Science. 182: 201-217.

Thomas, M. Connolly, \& Carolyn E. Begg. (2014). Database Systems: A Practical Approach to Design, Implementation and Management. International Computer Science Ser.5th Edn., Pearson. 